\title{
Sulistyowati, Rosmiati. Rancang Bangun Aplikasi Pengenalan Huruf, Angka, Dan Warna Bahasa Inggris Berbasis Android \\ RANCANG BANGUN APLIKASI PENGENALAN HURUF, ANGKA, DAN WARNA BAHASA INGGRIS BERBASIS ANDROID
}

\author{
Sulistyowati ${ }^{1}$, Rosmiati ${ }^{2}$ \\ Teknik Informatika ${ }^{1}$, Sistem Informasi ${ }^{2}$ - STMIK Palangkaraya \\ Jalan George Obos Nomor 114, Palangka Raya, Kalimantan Tengah \\ Email : sty.kireina@yahoo.com ${ }^{1}$, fayadhah@gmail.com ${ }^{2}$
}

\begin{abstract}
ABSTRAK
Salah satu pendidikan yang diberikan kepada anak adalah Bahasa Inggris. Dengan mengenalkan Bahasa Inggris sejak dini diharapkan nantinya anak-anak dapat mengenal huruf, angka, dan warna dengan menggunakan Bahasa Inggris tersebut. Permasalahan dari penelitian ini adalah bagaimana membuat aplikasi pengenalan huruf, angka, dan warna dalam Bahasa Inggris dengan konsep mendidik dan menghibur yang dapat membuat anak-anak. Sistem ini bertujuan untuk membantu anak-anak tertarik belajar Bahasa Inggris. Sistem dibuat menggunakan bahasa pemrograman Java. Sistem dapat menampilkan data huruf, data angka dan data warna yang sesuai, serta pertanyaan quis yang ditampilkan sudah sesuai dan dapat membantu anak memahami Bahasa Inggris.
\end{abstract}

\section{Kata kunci : Pengenalan Huruf, Angka, Warna, Android}

\section{PENDAHULUAN}

Belajar dengan media dapat diperkenalkan secara dini kepada anak, yaitu dengan programprogram aplikasi yang bersifat memadukan antar pendidikan (education) dengan hiburan (entertainment). Dengan program aplikasi tersebut diharapkan dapat menumbuh kembangkan minat, kreatifitas dan imajinasi anak sehingga anak-anak tertarik untuk belajar.

Salah satu pendidikan yang diberikan kepada anak adalah Bahasa Inggris. Dengan mengenalkan Bahasa Inggris sejak dini diharapkan nantinya anak-anak dapat mengenal huruf, angka, dan warna dengan menggunakan Bahasa Inggris tersebut.

Karakter anak usia dini lebih tertarik pada sesuatu yang menyenangkan seperti bermain, anakanak akan merasa terhibur dan senang melakukannya dan dengan kegiatan bermain dapat menjadi sarana untuk perkembangan anak. Bermain memberi kesempatan pada anak untuk langsung berperan dalam proses belajarnya dan sekaligus anak merasa kompeten tentang kemampuan mereka untuk belajar sehingga diperlukan media ajar yang dapat membantu guru maupun anak usia dini tertarik dalam proses belajar mengajar karena bersifat menyenangkan. Oleh karena itu, penulis tertarik untuk membuat aplikasi yang bersifat menghibur sekaligus mendidik untuk memudahkan penyampaian materi Bahasa Inggris kepada anak, dengan mengambil judul "Aplikasi Pengenalan Huruf, Angka, dan Warna dengan
Bahasa Inggris untuk anak Usia 3-6 Tahun Berbasis Android".

\section{TINJAUAN PUSTAKA}

Penelitian yang berjudul Media Pembelajaran Pengenalan Huruf, Angka, Warna Dan Bentuk Benda Berbasis Multimedia Untuk Anak Tk (Studi Kasus Paud. Waladun Sholihun), menjelaskan bahwa untuk memudahkan dalam penyampaian materi pembelajaran kepada anak-anak maka materi ini dikemas secara menarik dalam bentuk multimedia yang bersifat mendidik dan menghibur maka dibuatlah aplikasi CD interaktif pembelajaran pengenalan huruf, angka, warna dan bentuk benda berbasis multimedia untuk anak PAUD menggunakan Adobe Flash CS 5 (Yuliyana Rostiyati : 2014).

Penelitian tentang pembelajaran multimedia mengenalkan huruf, angka, warna, buah, sayuran, hewan, pekerjaan, kendaraan dan disertai kuis tebak gambar secara visual dan multimedia dalam 2 (dua) bahasa yaitu Bahasa Indonesia dan Inggris berbasis Android pernah dilakukan. Sistem diperuntukkan bagi anak 6-9 tahun (Sam'ani : 2019)

\subsection{Landasan Teori}

Anak Usia 3-6 Tahun

Pada usia 3-6 tahun kemapuan berkomunikasi dan berbahasa anak-anak berkembang secara 


$$
\begin{array}{r|l}
\text { Jurnal Sains Komputer dan Teknologi Informasi } & \text { Page } \\
\text { e-issn: 2655-7460. Volume 2 No.1, November 2019 } & 51-54
\end{array}
$$

sangat cepat, sehingga mulai mengucapkan beberapa kata serta mulai berbicara mengikuti tata bahasa serta mampu memahami aktivitas dalam gambar yang ditunjukkan (Ikapi : 2012).

\section{Android}

Android adalah sistem operasi untuk telepon seluler yang berbasis Linux. Android menyediakan platform terbuka bagi para pengembang buat menciptakan aplikasi mereka sendiri untuk digunakan oleh bermacam peranti bergerak (Putra : 2012).

\section{DESAIN SISTEM}

Use case merupakan langkah-langkah yang diikuti actor dalam memanfaatkan sistem berdasarkan pada kebutuhan fungsional sistem, maka use case dalam system pengenalan ini meliputi data huruf, data angka, data warna, serta bantuan penggunaan aplikasi. Gambar berikut merupakan use case sistem :

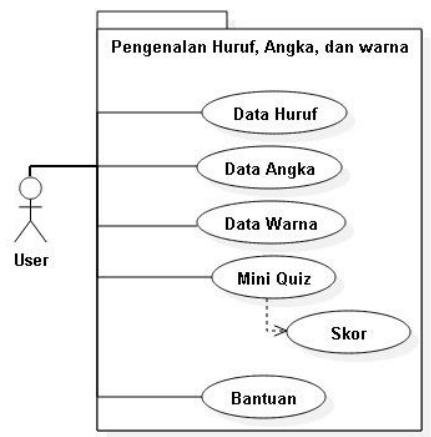

Gambar 1. Use Case

\section{Activity diagram Data Huruf}

User memilih menu data huruf maka sistem menampilkan form data huruf. Actor melihat dan mendengarkan sound data huruf.

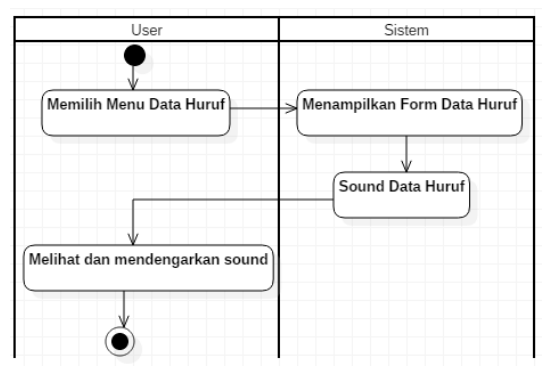

Gambar 2. Activity diagram Data Huruf

\section{Activity diagram Data Angka}

User memilih menu data anka maka sistem menampilkan form data angka. Actor melihat dan mendengarkan sound data angka.

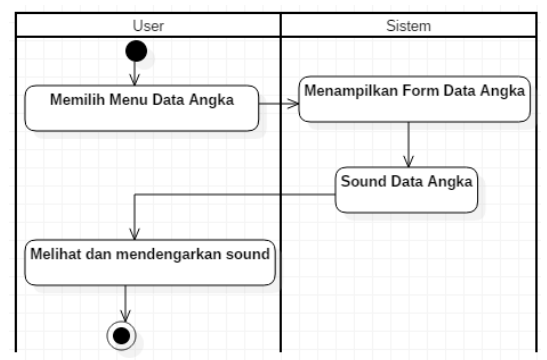

Gambar 3. Activity diagram Data Angka

\section{Activity diagram Data Warna}

User memilih menu data anka maka sistem menampilkan form data angka. Actor melihat dan mendengarkan sound data angka.

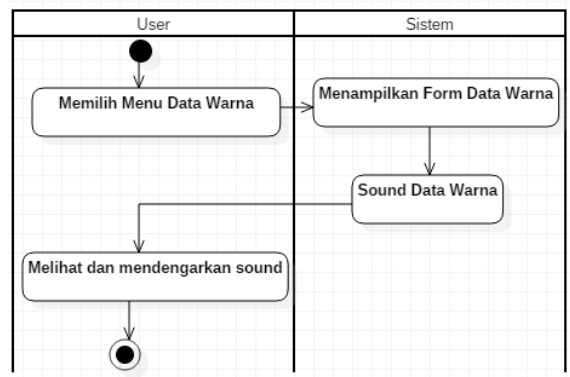

Gambar 4. Activity diagram Data Warna

\section{Activity diagram Mini Quiz.}

User memilih menu mini quiz maka sistem menampilkan form mini quiz. Actor menjawab pertanyaan latihan dan mendapatkan penilaian.

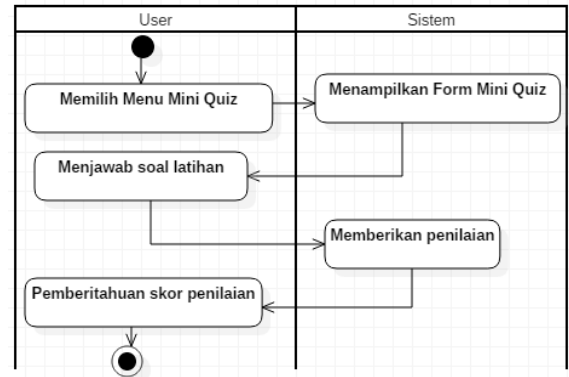

Gambar 4. Activity diagram Mini Quiz

\section{IMPLEMENTASI}

Tampilan antar muka menu utama sistem yang dihasilkan penelitian ini dapat dilihat pada gambar 5 berikut : 


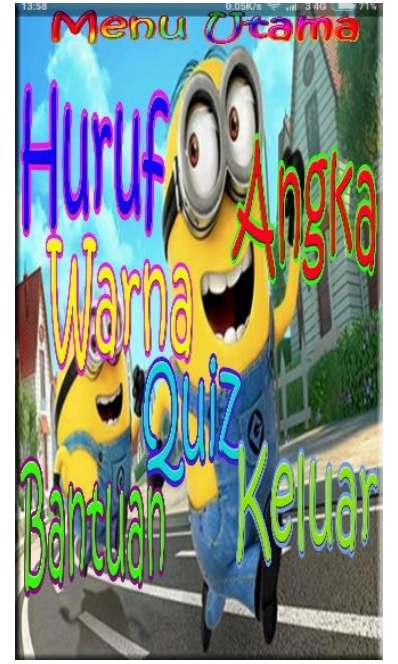

Gambar 5. Menu Utama Aplikasi

Menggambarkan pada saat pertama membuka aplikasi, dengan menampilkan menu-menu pilihan.

\section{Menu Huruf}

Saat menu huruf dipilih, maka proses selanjutnya adalah menampilkan data huruf dan ketika huruf di klik akan terdengar sound huruf dalam Bahasa Inggris, terlihat pada gambar 6.

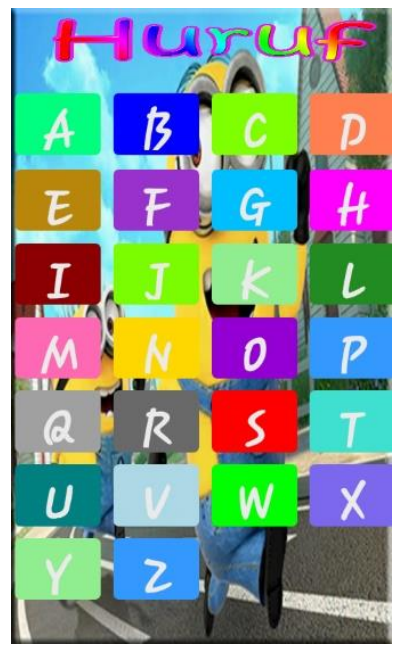

Gambar 6. Menu Huruf

\section{Menu Angka}

Saat menu angka dipilih, maka proses selanjutnya adalah menampilkan data angka dan ketika angka di klik akan terdengar sound angka dalam Bahasa Inggris, terlihat pada gambar 7.

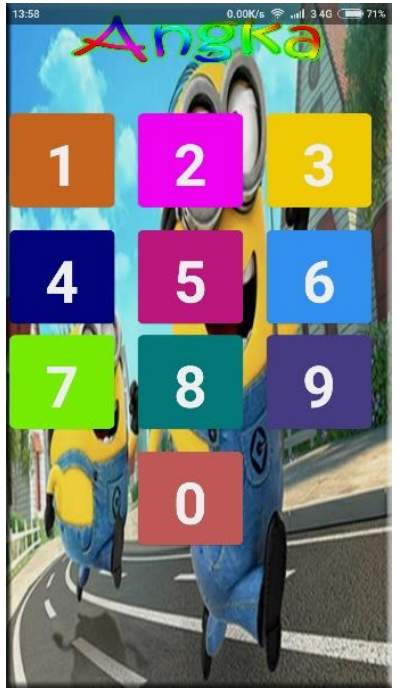

Gambar 7. Menu Angka

\section{Menu Warna}

Saat menu warna dipilih, maka proses selanjutnya adalah menampilkan data warna dan ketika warna di klik akan terdengar sound warna dalam Bahasa Inggris, terlihat pada gambar 8 .

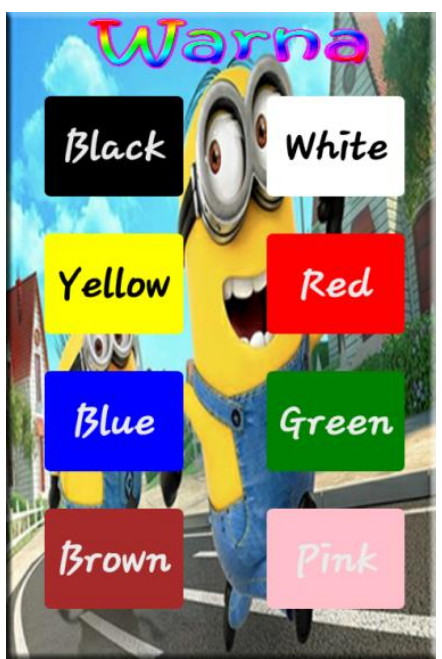

Gambar 8. Menu Warna

\section{Menu Quiz}

Saat menu quis dipilih, maka proses selanjutnya adalah menampilkan uji coba quiz, untuk jawaban benar atau salah akan muncul sound dan peringatan, terlihat pada gambar 9 


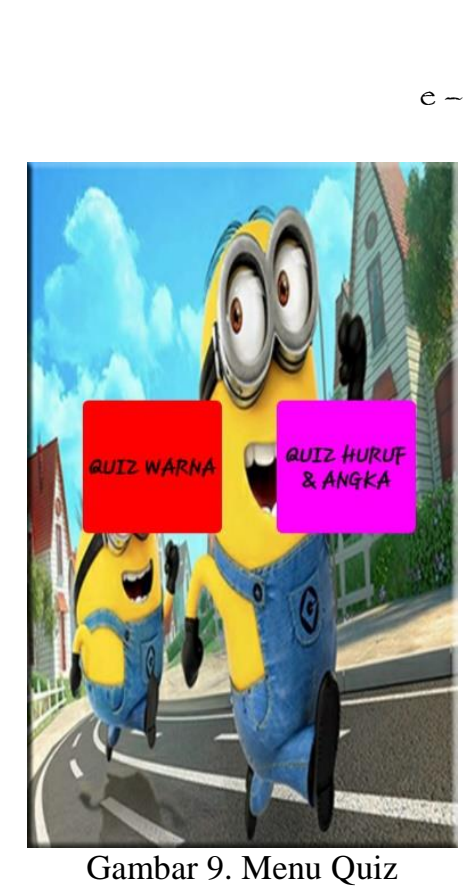

\section{KESIMPULAN DAN SARAN}

\subsection{Kesimpulan}

1. Telah dapat dihasilkan aplikasi pengenalan huruf, angka, dan warna dengan bahasa inggris untuk anak usia 3-6 tahun berbasis android.

2. Aplikasi dapat dimanfaatkan sebagai media pembelajaran untuk anak usia dini.

\subsection{Saran}

Aplikasi ini dapat dikembangkan dengan menambahkan lebih banyak angka dan warna, dengan tampilan yang lebih menarik untuk anakanak, serta dapat menambahkan animasi gerak.

\section{DAFTAR PUSTAKA}

Guritno, Suryo, Sudaryono dan Untung Rahrdja. 2010. Theory and application of IT Research Metodologi penelitian teknologi informasi. Andi Offset. Yogyakarta.

IKAPI, Anggota. 2012. Disney English My First Picture Dictionary Inggris-Indonesia. PT Gramedia Pustaka Utama. Jakarta.

Meggitt, Carolyn. 2012. Memahami Perkembangan Anak. PT Indeks Permata Puri Media. Jakarta Barat.

Mulyana, Eueung. 2012. App Inventor: Ciptakan Sendiri Aplikasi ANDROIDmu. Andi Offset. Yogyakarta.

Nugroho, Adi. 2010. Rekayasa Perangkat Lunak Berorientasi Objek Dengan Metode USDP
(Unified Software Development Process). Andi Offset. Yogyakarta.

Nur Rokhim, Yudhiwan 2014. Perancangan Aplikasi Pembelajaran Pengenalan Warna, Huruf Dan Angka Untuk Anak Usia Dini Dengan 3 Bahasa Berbasis Android. Universitas Muhammadiyah Surakarta. Surakarta.

Putra, Anna Arthdi, 2012. Buku Praktis Belajar Pemrograman Android. Edisi 1.0 Bahasa Indonesia Aplikasi Java Translate, SMS Sain, Aplikasi Bean Shell, Androbot.

Rostiyati, Yuliyana. 2014. Media Pembelajaran Pengenalan Huruf, Angka, Warna Dan Bentuk Benda Berbasis Multimedia Untuk Anak Tk (Studi Kasus Paud. Waladun Sholihun). Universitas Sebelas Maret Surakarta. Surakarta.

Sam'ani. Annisa, S., Heri., 2018. Rancang Bangun Aplikasi Pengawasan Dan Pengendalian Komputer Laboratorium Multimedia STMIK Palangkaraya. Jurnal Sains Komputer dan Teknologi Informasi. Vol 1 Issue 1 e-ISSN 2655-7460. https://doi.org/10.33084/jsakti.v1i1.548

Sam'ani, Qamaruzzaman, M. H, 2019. Rancang Bangun Visualisasi Pembelajaran Berbasis Android Untuk Anak. Jurnal SISTEMASI. Vol 8 No 3 e-ISSN 2540-9719. DOI : https://doi.org/10.32520/stmsi.v8i3.518

Siahaan, Daniel. 2012. Analisis Kebutuhan Dalam Rekayasa Perangkat Lunak. Andi Offset. Yogyakarta.

Sulistyowati, Rohmah, A., Dwianto, A. Analisa Dan Perancangan Aplikasi Surat Menyurat Pada Badan Meteorologi, Klimatologi dan Geofisika (BMKG) Palangka Raya Berbasis Web. Jurnal Sains Komputer dan Teknologi Informasi. Vol 1 Issue 1 e-ISSN 2655-7460. https://doi.org/10.33084/jsakti.v1i2.873.

Utomo, Wiranto Herry. 2010. Pemodelan Basis Data Berorientasi Objek. Andi Offset. Yogyakarta. 